\title{
Effects of double-blind controlled calcium supplementation on calcium absorption in Chinese children measured with stable isotopes $\left({ }^{42} \mathrm{Ca}\right.$ and $\left.{ }^{44} \mathrm{Ca}\right)$
}

\author{
BY WARREN T. K. LEE* AND SOPHIE S. F. LEUNG \\ Department of Paediatrics, Faculty of Medicine, The Chinese University of Hongkong, \\ Shatin, Hongkong \\ AND Y. C. XU AND S. H. WANG \\ Department of Nutrition and Food Hygiene, Sun Yat Sen University of Medical Sciences, \\ Guangzhou, China \\ AND W. P. ZENG \\ Jiangmen Epidemic Station, Jiangmen, Guangdong Province, China \\ AND JOSEPH LAU \\ Centre for Clinical Trials and Epidemiological Research, Faculty of Medicine, The Chinese \\ University of Hongkong, Shatin, Hongkong \\ AND SUSAN J. FAIRWEATHER-TAIT \\ Institute of Food Research, Norwich Laboratory, Norwich Research Park, Colney, \\ Norwich NR4 7UA
}

(Received I March 1994-Revised 1 June 1994-Accepted 24 June 1994)

\begin{abstract}
A double-blind controlled Ca supplementation trial was conducted for 6 months in thirty-four 7-year-old Chinese children from Hongkong and Jiangmen, China. The children were randomly allocated to the study group ( $n$ 17) or control group ( $n$ 17), and a $\mathrm{CaCO}_{3}$ tablet $(300 \mathrm{mg} \mathrm{Ca}$ ) or a placebo tablet was taken daily. True fractional $\mathrm{Ca}$ absorption (TFCA) was evaluated before and after the trial using stable isotopes: $8 \mathrm{mg}{ }^{4} \mathrm{Ca}$ mixed in $100 \mathrm{~g}$ chocolate milk was given after an intravenous injection of $0.75 \mathrm{mg}{ }^{42} \mathrm{Ca}$. There was no significant difference in baseline TFCA between the study group (60.6 (SD 11.4)\%) and the controls (58.2 (SD 9.0)\%; $P=0.55)$. Serum 25-hydroxycholecalciferol levels were comparable between the two groups $(P=0.71)$. After 6 months, TFCA of the study group (55.6 (SD 12.7) \%) was significantly lower than that of the controls (64.3 (SD 10.7) $\% ; P=0.015)$. By comparing the individual changes in TFCA after the trial between the two groups there was a nonsignificant reduction in TFCA (5.03 (SD 12.4)\%; $P=0.11$, Wilcoxon signed-rank test) in the study group (60.6-55.6\%), whereas a significant increase in TFCA (6.17 (sD 7.7) $\% ; P=0.004$, Wilcoxon signed-rank test) was observed in the controls (58.2-64.3\%). The differential in TFCA between the two groups after 6 months was significantly different $(P=0.001)$, and remained significant after adjustment for baseline dietary intakes, weight and height by multiple-regression analysis $(P=0.003)$. If the mechanism of TFCA from chocolate milk in response to the treatment effects is similar to that from the total diet, then our results suggest that children with adequate vitamin D status can adapt to a change in Ca intake by adjusting the efficiency of TFCA. In corollary, children on habitually-low Ca diets have a higher TFCA than the counterparts with higher $\mathrm{Ca}$ diets.
\end{abstract}

Calcium: Childhood: Nutritional supplementation: Stable-isotopes 
During childhood an adequate $\mathrm{Ca}$ intake is essential for bone development and mineralization (Johnston et al. 1992; Lee et al. 1993a, b). Ca intakes vary from nation to nation in the world (Food and Agriculture Organization/World Health Organization, 1962; Nordin \& Marshall, 1988). In Southern China the majority of Chinese children cease to use milk after 1 year of age. Ca intakes of Chinese children have been reported to be about $300 \mathrm{mg} / \mathrm{d}$ (Chen, 1986; Lee et al. 1993 b, 1994). Whether children accustomed to this level of intake are able to absorb adequate $\mathrm{Ca}$ to achieve a $\mathrm{Ca}$ balance appropriate for bone mineralization is not known (Matkovic et al. 1990). In fact, there have been few studies on the efficiency of $\mathrm{Ca}$ absorption in growing children. Early balance studies in India and Sri Lanka showed that children could adapt to an habitual Ca intake of about $300 \mathrm{mg} / \mathrm{d}$ and still maintain a positive Ca balance (Nicholls \& Nimalasuriya, 1939; Begum \& Pereira, 1969). Ca absorption was approximately $50 \%$ in rural Indian children subsisting on a diet with as low as $200 \mathrm{mg} \mathrm{Ca} / \mathrm{d}$. In a recent study our research group has estimated the efficiency of $\mathrm{Ca}$ absorption in 7-year-old Chinese children using the doubly-labelled technique with oral administration of extrinsically labelled ${ }^{44} \mathrm{Ca}$ in $100 \mathrm{~g}$ chocolate milk (120 mg Ca/kg) and an intravenous administration of ${ }^{42} \mathrm{Ca}$. These study children were maintained on self-selected diets in the range 172 to $1641 \mathrm{mg} \mathrm{Ca} / \mathrm{d}$. The mean true fractional Ca absorption (TFCA) of the lower-Ca-intake children was significantly higher than that of the higher-Ca-intake counterparts (63v. 55\%;P=0.016; Lee et al. 1994).

The aim of the present trial was to investigate prospectively whether growing children are able to adapt to a change in $\mathrm{Ca}$ intake by regulating the efficiency of intestinal $\mathrm{Ca}$ absorption. In recent years the use of a stable (non-radioactive) dual-label isotope technique has provided a safe, accurate and reproducible means of determining true $\mathrm{Ca}$ absorption in infants and children (Yergey et al. 1987; Hillman et al. 1988; Miller et al. 1988). A 6-month randomized double-blind controlled $\mathrm{Ca}$ supplementation trial was conducted in a group of thirty-four Chinese children; the trial subjects were the same as those participating in our previous study (Lee et al. 1994). TFCA was evaluated by the technique of stable isotopes coupled with thermal-ionization quadrupole mass spectrometry before and 6 months after the trial. The present $\mathrm{Ca}$ supplementation trial commenced on the day after the baseline absorption test. The values for $\mathrm{Ca}$ absorption obtained from the previous study were used as baseline values for TFCA in the current trial. After 6 months the efficiency of $\mathrm{Ca}$ absorption was re-evaluated.

SUBJECTS, MATERIALS AND METHODS

Thirty-four 7-year-old Chinese children (eighteen boys, sixteen girls) took part in the study. They were the same subjects as those from our previous absorption study (Lee et al. 1994). Twenty-two of them were Hongkong Chinese children (twelve boys, ten girls) randomly selected from an ongoing cohort study of growth and nutrition (Leung \& Lui, 1990; Lee et al. 1993a). The cohort has been followed-up since birth. The remaining twelve children (six boys, six girls) were randomly selected in a primary school from Jiangmen, a city in Guangdong Province of Southern China. Hongkong and Jiangmen are close cities located in the Pearl River delta of Guangdong Province, and the study children from both locations are ethnic Cantonese. All the study children fulfilled the selection criterion that they were healthy and did not have any previous history of metabolic diseases or any recent episodes of bone fractures that might interfere with Ca metabolism.

All the study children were randomly allocated to receive either Ca supplement $(n 17)$ or placebo $\left(n\right.$ 17). The $\mathrm{Ca}$ supplement was cherry-flavoured chewable $\mathrm{CaCO}_{3}$ tablet (TumsEx; Smithkline Beecham, Weybridge, Surrey). Each tablet contained $700 \mathrm{mg} \mathrm{CaCO}$ ( $300 \mathrm{mg}$ elemental $\mathrm{Ca}$ ). The placebo used was a Ca-free sucrose tablet of similar colour, shape and taste, and was produced by the same manufacturer. The study children from 
Jiangmen received Ca-supplement or placebo tablets at school. The tablets were dispensed daily to each child in the class by the same teacher on a $6 \mathrm{~d} /$ week basis. Each child took one tablet immediately after school breakfast. During vacations, appropriate numbers of tablets were distributed to the parents to be taken at home. On the other hand, the study children from Hongkong went to different schools so the $\mathrm{Ca}$ supplement and placebo tablets were distributed to the parents to be taken at home. The children took one tablet every morning after breakfast. Throughout the trial period, all the study children, teachers, parents and the field workers were blind to the design of the controlled trial. The controlled trial lasted for 6 months. Compliance was checked by counting the number of tablets taken by each child after the trial.

\section{Weight and height measurements}

Standing height was measured without shoes using a stadiometer (Technical Services Unit, The Chinese University of Hongkong). Unclothed weight of the Hongkong children was measured using a Seca electronic scale (Vogel \& Halke GmbH \& Co., Hamburg, Germany), whereas the weight of Jiangmen children was estimated using a beam balance (Model: TGT-100; Lichepai, Guangdong, China).

\section{Dietary assessments}

Dietary assessments were performed before the trial. Food intake of the Hongkong group was assessed by a research dietitian (W.T.K.L.) using the method of dietary history, and cross-checked with a quantitative food-frequency questionnaire and $24 \mathrm{~h}$ recall (Burke, 1947; Bingham, 1987; Jain, 1989). Details of the procedures have been described by Lee $e t$ al. (1993a). Dietary intake of Jiangmen children was assessed by the same quantitative food-frequency questionnaire as that used in the Hongkong group. The procedures have been described elsewhere (Lee et al. 1994). Calculation of nutrient intake was performed using a local-food database program (Lee et al. 1993a) with food items compiled from the following food tables: Church \& Church (1975), Institute of Health (1980), Paul \& Southgate (1978), Tung et al. (1961), Department of Health, Education \& Welfare (1972) and Watt \& Merrill (1983), and data from food manufacturers and food chemists.

\section{Preparation and administration of stable isotopes}

TFCA was determined by a double-label stable-isotope technique using ${ }^{42} \mathrm{Ca}$ and ${ }^{44} \mathrm{Ca}$. Doses of ${ }^{44} \mathrm{Ca}$ for oral administration and ${ }^{42} \mathrm{Ca}$ for intravenous injection were estimated using the basis of $0.2-0.5 \mathrm{mg}{ }^{44} \mathrm{Ca} / \mathrm{kg}$ body weight and $0.02-0.1 \mathrm{mg}{ }^{42} \mathrm{Ca} / \mathrm{kg}$ body weight (Yergey et al. 1987). Two enriched $\mathrm{Ca}$ isotopes: ${ }^{42} \mathrm{Ca}(83.20$ atom $\%)$ and ${ }^{44} \mathrm{Ca}$ $\left(96.40\right.$ atom \%) in the form of $\mathrm{CaCO}_{3}$ (Technical and Optical Equipment, Tottenham, London) were prepared as described previously (Lee et al. 1994). Each $4 \cdot 3 \mathrm{ml}$ dose of ${ }^{44} \mathrm{Ca}$ was sealed in a polyethylene tube and kept at $-20^{\circ}$. Each $2 \mathrm{ml}$ dose of ${ }^{42} \mathrm{Ca}$ solution for injection was sealed in a glass ampoule and autoclaved. Samples of ${ }^{42} \mathrm{Ca}$ solution underwent routine sterility testing in the Pharmacy of Prince of Wales Hospital, Hongkong. The final concentrations of the oral dose of ${ }^{44} \mathrm{Ca}$ solution and intravenous dose of ${ }^{42} \mathrm{Ca}$ solution were 1.83 and $0.359 \mathrm{mg} / \mathrm{ml}$ respectively. The exact quantities of isotopes given to each subject were precisely weighed with an electronic scale accurate to $0.001 \mathrm{mg}$.

The study children were fasted overnight before the absorption test. ${ }^{42} \mathrm{Ca}$ was administered slowly into the antecubital vein and then flushed with $5 \mathrm{ml}$ normal saline $(9 \mathrm{~g} \mathrm{NaCl} / 1) .{ }^{44} \mathrm{Ca}$ was mixed in $100 \mathrm{~g}$ chocolate milk. The amount of $\mathrm{Ca}$ in the chocolate milk was $120 \mathrm{mg} / \mathrm{kg}$ as determined by atomic absorption spectrometry (Nordin, 1976). The ${ }^{44} \mathrm{Ca}$-enriched chocolate milk was then taken by the subject immediately after the injection. No food was allowed for $2 \mathrm{~h}$ after the test. After $2 \mathrm{~h}$ the children were given a 
standard breakfast (one $75 \mathrm{~g}$ sponge cake and $250 \mathrm{ml}$ fruit juice). A urine sample of $500 \mathrm{ml}$ was collected starting exactly $24 \mathrm{~h}$ after the test to determine the ratios of isotopes present in the urine. The urine was collected in an acid-washed bottle until the volume of urine reached the $500 \mathrm{ml}$ mark.

\section{Determination of isotope ratios in the enriched urine samples}

The urine samples were digested in concentrated $\mathrm{HNO}_{3}$ using a microwave digester (CEM Model MD5-2000 Microwave Sample Preparation System; CEM Corporation, Matthews, N.C., USA), and the inorganic impurities in the digested urine samples were removed by loading the urine samples into ion-exchange columns (Dowex 50W-hydrogen, $8 \%$ crosslinking, 100-200 dry-mesh resin, Aldrich Chemical Co., Poole, Dorset), the sample was then washed with concentrated $\mathrm{HNO}_{3}$ followed by $\mathrm{HCl}$. The isotope ratios of the purified samples were determined by thermal-ionization mass spectrometry (THQ; Finnegan-Mat $\mathrm{GmbH}$, Bremen, Germany) using the double-filament technique (Heumann, 1988). The principles of the methods and the detailed laboratory procedures have been described previously (Lee et al. 1994).

\section{Calculation of true fractional calcium absorption}

The calculation of percentage TFCA was based on the assumption that both the intravenous and orally administered $\mathrm{Ca}$ isotopes are metabolized at the same rate once the state of equilibrium has been achieved. The percentage absorption from the oral dose was determined according to the following equation (Yergey et al. 1987):

$$
\% \text { TFCA }=\frac{\left(\text { na }^{44} \mathrm{Ca}\right)\left({ }^{42} \mathrm{Ca} i v\right) \times \Delta \% \mathrm{XS}^{44} \mathrm{Ca} \times 100}{\left(\mathrm{na}^{42} \mathrm{Ca}\right)\left({ }^{44} \mathrm{Ca} \text { oral }\right) \times \Delta \% \mathrm{XS}{ }^{42} \mathrm{Ca}},
$$

where $\mathrm{na}$ is the natural abundance of the two isotopes, iv (intravenous) and oral refer to the exact dose administered, and $\Delta \% \mathrm{XS}$ is the degree to which a particular ratio differs from the natural ratios.

\section{Determination of serum level of 25-hydroxycholecalciferol (25-OHD)}

Serum level of 25-OHD was determined at the beginning of the trial (Lee et al. 1994) using a competitive protein assay as described previously (Woo et al. 1990; Lee et al. 1994). Twenty study children consented to have blood taken for the 25-OHD assay. Venous blood $(2 \mathrm{ml})$ was withdrawn from the antecubital vein and the serum was separated. 25-OHD was extracted from the serum using acetonitrile and then separated with a SepPak C-18 cartridge (Waters Associated, Milford, MA, USA). The extract was analysed by a competitive protein-binding assay using a commercial kit (Amersham International, Amersham, Bucks.).

\section{Statistical methods}

Owing to the small sample size and the observed skewness of some variables, the underlying assumptions of parametric tests may not be valid in the analysis. The non-parametric Mann-Whitney $U$ test was used to compare intergroup differences in various variables, whereas non-parametric Wilcoxon signed rank test was used to test intraindividual changes in TFCA over the 6-month trial. Multiple-regression analysis was used to identify the relative contribution of initial $\mathrm{Ca}$ intake, treatment effect ( $\mathrm{Ca}$ or placebo), and the effect of interaction between baseline $\mathrm{Ca}$ intake and the treatment effect ( $\mathrm{Ca}$ or placebo) on the prediction of the changes in TFCA over the 6-month period. Significance level was set at $P<0.05$, two-tailed. Statistical analysis was performed using Statistical Package for Social Sciences (1990) procedure. 


\section{Ethical considerations}

The study protocol was approved by the Ethics Committees of The Faculty of Medicine, The Chinese University of Hongkong, and the Institute of Food Research, Norwich Laboratory, UK. Informed consent was obtained from the parents.

\section{RESULTS}

There was no drop-out from the trial. The mean compliance of the study and control groups were 96.20 (SD 16) and 92.8 (SD 14) \% respectively by counting the number of tablets taken by each subject after the trial. There was no significant difference in the mean compliance between the study and control groups $(P>0.05)$.

\section{Baseline characteristics of the study children}

The mean Ca intake of the twenty-two Hongkong children was 693 (SD 410) $\mathrm{mg} / \mathrm{d}$; they had a wider range of $\mathrm{Ca}$ intake $(185-1641 \mathrm{mg} / \mathrm{d})$ because some of them consumed milk regularly. Detailed dietary assessments of these Hongkong cohort children since infancy have shown that the majority of the children consumed milk on a regular basis. Cow's milk was the chief source of $\mathrm{Ca}$ among the study children in Hongkong. Children from Jiangmen in mainland China, however, consumed little milk after 1 year of age because their dietary habits were less influenced by the West. The main sources of $\mathrm{Ca}$ among the Jiangmen study children were dark-green leafy vegetables, cereals and bean products. The mean $\mathrm{Ca}$ intake of the twelve children from Jiangmen was 381 (SD 103, range 172-552) $\mathrm{mg} / \mathrm{d}$.

Table 1 shows the baseline characteristics of the study children allocated to either the study group or control group. The mean $\mathrm{Ca}$ intake of the study group was not significantly different from that of the control group $(P=0.076) ; P$ and protein intakes for the study group were significantly higher $(P=0.029$ and $P=0.048$ respectively) than those for the control group. Weight and height of the study group were not significantly different from those for the control group ( $P=0.48$ and $P=0.67$ respectively). The initial TFCA of the study group was not significantly different from that of the control group (60.6 (SD 11.4, $95 \%$ CI 54.8-66.5) \% v. 58.2 (SD 9.0, 95\% CI 53.6-62.8) \%; $P=0.55$ ). Table 2 summarizes the baseline characteristics of boys and girls in the supplementation trial. There were no significant sex differences in dietary intakes, body size and initial TFCA.

The mean baseline serum 25-OHD levels $(\mathrm{ng} / \mathrm{ml})$ for the study and control groups were respectively $34.8(\mathrm{SD} 8 \cdot 2, n 10)$ and 32.6 (SD 7.5, $n$ 10). There was no significant difference in serum 25-OHD level between the study and control groups $(P=0.71$; Table 1$)$. Also, there was no significant difference in 25-OHD levels between boys and girls (33.6 (SD 8.2) v. 33.8 (SD 7.7) $\mathrm{ng} / \mathrm{ml} ; \boldsymbol{P}=0.94$ ). A serum $25-\mathrm{OHD}$ level below $10 \mathrm{ng} / \mathrm{ml}$ has been used by some investigators as a biochemical index for vitamin D deficiency (Grindulis et al. 1986) therefore, the vitamin D nutritional status of the study children should be adequate.

\section{Effects of controlled calcium supplementation on calcium absorption}

After 6 months there was a significant difference in TFCA between the study group (55.6 (SD 12.7) \%) and the control group (64.3 (SD 10.7)\%; $P=0.015$; Table 1). Fig. 1 shows the changes in TFCA for individual subjects in the study and control groups over the 6month period. There was a tendency towards a decrease in TFCA among the individuals in the study group, whereas the TFCA of the individuals in the control group tended to increase after the trial. After 6 months the mean TFCA of the study group was reduced by 5.03 (SD 12.4$) \%$ to 55.6 (SD 12.7$) \%(95 \%$ CI $49 \cdot 1-62.1 \% ; P=0.11$ by Wilcoxon signed rank test). Nevertheless, the control group showed a significant increase in TFCA $(6.17$ (SD 7.7) \%) to 64.3 (SD 10.7, 95\% CI 58.9-69.8) \%; $P=0.004$ by Wilcoxon signed 
Table 1. Comparisons of mean dietary intakes, body size, initial and final true fractional calcium absorption (TFCA) in groups of 7-year-old Hongkong and mainland Chinese children receiving either a Ca supplement (study group) or a placebo (control group)*

(Values are means and standard deviations for seventeen subjects per group)

\begin{tabular}{|c|c|c|c|c|c|c|c|}
\hline & \multicolumn{3}{|c|}{ Study group } & \multicolumn{3}{|c|}{ Control group } & \multirow{2}{*}{$\begin{array}{c}\text { Statistical } \\
\text { significance } \\
\text { of difference } \\
\text { between } \\
\text { groups: } P \dagger\end{array}$} \\
\hline & Mean & SD & Range & Mean & SD & Range & \\
\hline $\mathrm{Ca}(\mathrm{mg} / \mathrm{d})$ & 672 & 392 & $298-1641$ & 494 & 324 & $172-1516$ & $0 \cdot 076$ \\
\hline Energy $(\mathbf{K} \mathbf{J} / \mathrm{d})$ & 7055 & 2170 & $3726-12951$ & 6235 & 2183 & $3224-11254$ & $0-28$ \\
\hline Ca:energy (mg/MJ) & 91.8 & 30 & $40 \cdot 2-164 \cdot 0$ & $76 \cdot 3$ & 26 & $31 \cdot 8-134.7$ & 0.10 \\
\hline$P(\mathrm{mg} / \mathrm{d})$ & 980 & 328 & $591-1803$ & 798 & 294 & $436-1707$ & 0.048 \\
\hline $\mathrm{Ca}: \mathrm{P}$ & 0.661 & $0-2$ & $0.3-1 \cdot 18$ & 0.586 & 0.18 & $0.34-0.91$ & 0.25 \\
\hline Protein $(\mathrm{g} / \mathrm{d})$ & $76 \cdot 1$ & 17 & $40-103$ & $64 \cdot 8$ & $22 \cdot 3$ & $38-117$ & 0.029 \\
\hline Wt (kg) & $21 \cdot 3$ & 2.9 & $17 \cdot 2-27 \cdot 9$ & $20 \cdot 7$ & $2 \cdot 6$ & $17 \cdot 6-27 \cdot 4$ & 0.48 \\
\hline Height (m) & $1 \cdot 20$ & $0-04$ & $1 \cdot 14 \cdot 1 \cdot 26$ & $1 \cdot 19$ & 0.04 & $1 \cdot 14-1 \cdot 29$ & 0.67 \\
\hline TFCA (\%): Initial & $60 \cdot 6$ & $11 \cdot 4$ & $46 \cdot 0-84 \cdot 6$ & $58 \cdot 2$ & $9 \cdot 0$ & $47 \cdot 3-78 \cdot 5$ & 0.55 \\
\hline Final & 55.6 & $12 \cdot 7$ & $39 \cdot 5-90 \cdot 7$ & $64 \cdot 3$ & 10.7 & $43 \cdot 8-95 \cdot 5$ & 0.015 \\
\hline
\end{tabular}

* For details of subjects and procedures, see pp. 312-314.

$\dagger$ Mann-Whitney $\mathbf{U}$ test.

Table 2. Comparisons of mean dietary intakes, body size, and initial true fractional calcium absorption (TFCA) between 7-year-old Hongkong and mainland Chinese boys and girls

(Values are means and standard deviations)

\begin{tabular}{|c|c|c|c|c|c|c|c|}
\hline \multirow{2}{*}{$n \ldots$} & \multicolumn{3}{|c|}{$\begin{array}{c}\text { Boys } \\
18\end{array}$} & \multicolumn{3}{|c|}{$\begin{array}{c}\text { Girls } \\
16\end{array}$} & \multirow{2}{*}{$\begin{array}{c}\text { Statistical } \\
\text { significance } \\
\text { of difference } \\
\text { between } \\
\text { groups: } P \dagger\end{array}$} \\
\hline & Mean & SD & Range & Mean & SD & Range & \\
\hline $\mathrm{Ca}(\mathrm{mg} / \mathrm{d})$ & 641 & 407 & $172-1641$ & 517 & 312 & $185-1516$ & $0 \cdot 39$ \\
\hline Energy $(K J / d)$ & 6909 & 2472 & $3224-12591$ & 6348 & 1836 & $3786-11254$ & 0.58 \\
\hline $\mathrm{Ca}: \operatorname{energy}(\mathrm{mg} / \mathrm{MJ})$ & $88 \cdot 7$ & $31 \cdot 8$ & $40 \cdot 2-164 \cdot 1$ & $78 \cdot 9$ & $24 \cdot 2$ & $31 \cdot 8-134.7$ & $0 \cdot 35$ \\
\hline$P(\mathrm{mg} / \mathrm{d})$ & 938 & 348 & $436-1803$ & 834 & 287 & $501-1707$ & $0 \cdot 30$ \\
\hline $\mathrm{Ca}: \mathrm{P}$ & 0.65 & 0.21 & $0 \cdot 3-1 \cdot 18$ & 0.60 & 0.16 & $0.34-0.91$ & 0.45 \\
\hline Protein (g/d) & $72 \cdot 1$ & $21 \cdot 7$ & $38-115$ & $68 \cdot 6$ & $19 \cdot 2$ & $42-117$ & 0.63 \\
\hline Wt (kg) & $20 \cdot 9$ & 1.8 & $18 \cdot 1-24 \cdot 7$ & $21 \cdot 1$ & $3 \cdot 7$ & $17 \cdot 2-27 \cdot 9$ & 0.70 \\
\hline Height (m) & $1 \cdot 19$ & 0.03 & $1 \cdot 14-1 \cdot 24$ & $1-21$ & 0.04 & $1 \cdot 15-1 \cdot 30$ & 0.19 \\
\hline Initial TFCA (\%) & $60 \cdot 1$ & $12 \cdot 1$ & $46-84 \cdot 6$ & $58 \cdot 6$ & $7 \cdot 7$ & $50 \cdot 1-78 \cdot 5$ & $1 \cdot 0$ \\
\hline
\end{tabular}

† Mann-Whitney U test.

rank test). The differential in TFCA between the study and control groups after the 6-month trial was significantly different $(P=0 \cdot 001)$, and the significant difference remained even after adjusting for baseline dietary intakes of $\mathrm{Ca}, \mathbf{P}$ and protein, weight and height $(P=$ 0.0035). Multiple-regression analysis was used to identify the relative contribution of initial $\mathrm{Ca}$ intake, treatment effect (Ca or placebo), and the effect of interaction between initial $\mathrm{Ca}$ intake and the treatment effect (Ca or placebo) on the predicted change in TFCA over the 6-month period. The results show that baseline $\mathrm{Ca}$ intake did not predict the changes in TFCA either in the study group or control group over the 6-month period $(P=0.93$ for 

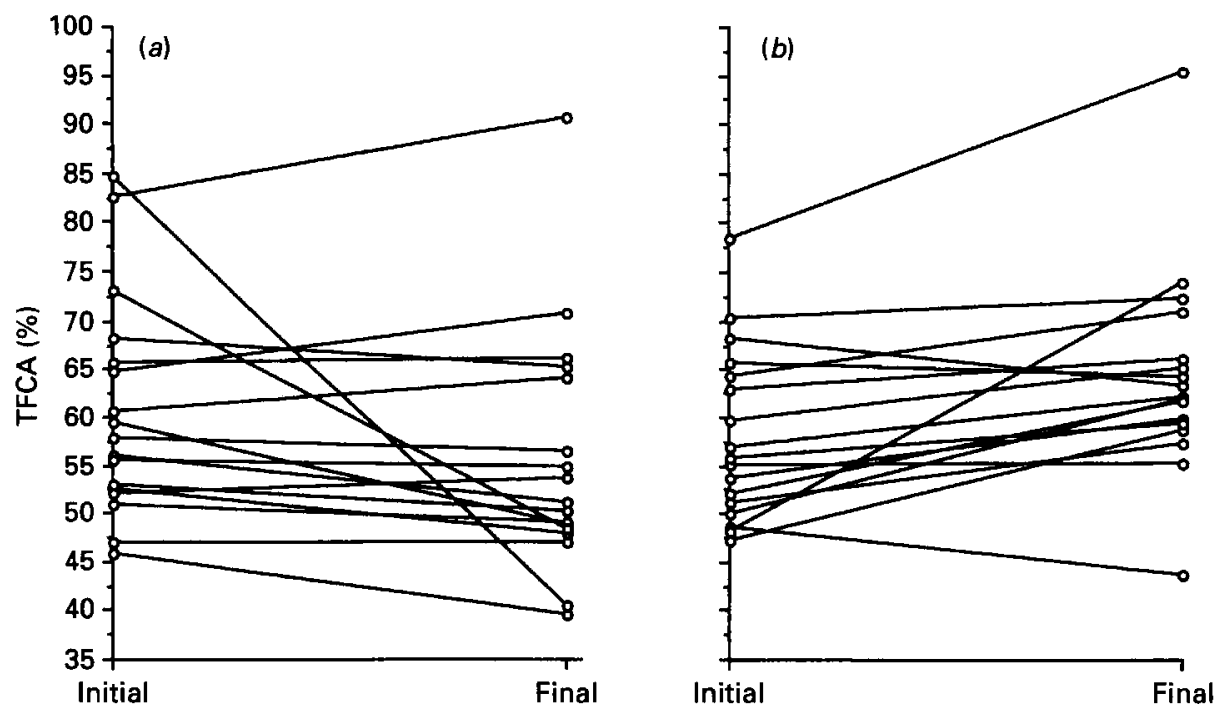

Fig. 1. Changes of true fractional calcium absorption (TFCA; \%) of thirty-four Hongkong and mainland Chinese children receiving (a) Ca supplement (study group, $n=17$ ) or $(b)$ placebo (control group; $n$ 17) after a 6-month controlled $\mathrm{Ca}$ supplementation trial using a double-label stable isotope technique. For details of subjects and procedures, see pp. 312-314.

main effect, $P=0.62$ for interaction effect). However, the treatment effect remained a significant independent variable to predict the difference between the initial and final TFCA $(P=0.048)$.

\section{DISCUSSION}

To our knowledge, this is the first double-blind controlled $\mathrm{Ca}$ supplementation trial to study the effects on changes in TFCA among Chinese children using the technique of doubly-labelled stable isotopes with ${ }^{44} \mathrm{Ca}$ administered orally in chocolate milk. The compliance rate of the trial participants was greater than $90 \%$ and the compliance was consistent throughout this short-duration study. The mean serum concentration of $25-$ OHD for the twenty study children was within the normal range even in the winter season; therefore, the vitamin D nutritional status of the study children should not be a limiting factor to facilitate $\mathrm{Ca}$ absorption. There was no significant difference in either the compliance rate or vitamin D nutritional status between the study and control groups; hence, these two factors should not be confounding factors in the difference in TFCA between the study and control groups on completion of the trial.

There was a wide individual variation in both the individual values for TFCA, and the change in TFCA among the children in response to treatment effects (Fig. 1). In the study group, two boys with mean $\mathrm{Ca}$ intakes at about 300 and $380 \mathrm{mg} / \mathrm{d}$ had markedly reduced TFCA (from 84.6 to $40.5 \%$ and from 73.1 to $48.4 \%$ respectively) after the trial, whereas in the control group, a boy and a girl with mean $\mathrm{Ca}$ intakes at about 270 and $325 \mathrm{mg} / \mathrm{d}$ had TFCA values which were markedly increased (from 48.1 to $74.2 \%$ and from 78.5 to $95.5 \%$ respectively) after the study. Replicate laboratory analyses yielded consistent results. All four children were perfectly normal; however, their dietary Ca intakes were on the low side. Such a magnitude in variation in the change of TFCA has also been reported in a shortterm milk-supplementation study (Fairweather-Tait et al. 1989).

The children in the study group had a much higher dietary $\mathrm{Ca}$ intake compared with 
those in the control group throughout the 6-month controlled Ca supplementation trial. At the end of the trial the TFCA of the control group was significantly higher than that of the study group. In addition, by comparing the individual changes in TFCA over the 6-month period for the study and control groups, a significant increase in TFCA was observed in the control group, whereas there was a non-significant reduction in TFCA in the study group after 6 months. If TFCA from the total diet is similar to that from chocolate milk, then the results from the present study suggest that growing children are able to increase the efficiency of intestinal $\mathrm{Ca}$ absorption to meet the escalated demand for $\mathrm{Ca}$ for bone mineralization. Further study is required to determine whether $\mathrm{Ca}$ intake is a major determinant for increasing the rate of $\mathrm{Ca}$ absorption. On the other hand, to increase $\mathrm{Ca}$ intake in growing children by using $\mathrm{Ca}$ supplements alters the state of $\mathrm{Ca}$ equilibrium by downward regulation of the $\mathrm{Ca}$ absorptive mechanism. The findings of the present trial are in line with several adult studies in that fractional $\mathrm{Ca}$ absorption is negatively related to habitual Ca intake (Malm, 1958; Heaney et al. 1975). During the period of skeletal development an increased demand for $\mathrm{Ca}$ for bone mineralization may enhance the production of parathyroid hormone and 1,25-dihydroxycholecalciferol, which in turn would stimulate the synthesis of Ca-binding protein to facilitate intestinal uptake of $\mathrm{Ca}$ (Hegsted et al. 1952; Norman et al. 1981; Norman, 1990; Chan et al. 1992). Furthermore, a reduction in urinary $\mathrm{Ca}$ excretion has been documented in childhood, adolescence and adulthood (Hegsted et al. 1952; Begum \& Pereira, 1969; Matkovic et al. 1990). Therefore, a successful nutritional adaptation may happen in children as a result of hormonal mediation such that an adequate amount of $\mathrm{Ca}$ may be retained to achieve a positive $\mathrm{Ca}$ balance for skeletal mineralization. Hongkong and Jiangmen are located in the subtropical geographical region; there is an abundance of sunshine throughout the year. The study children in this age-group spent a lot of time on outdoors activities; therefore, they should obtain most of their vitamin D by regular exposure to the sun. The serum 25-OHD concentration of the study children was determined in the winter, and the results of the analysis were found to be normal. Furthermore, in the present trial there was no significant difference in serum concentration of 25-OHD between the study and control groups. Therefore, an adequate vitamin D nutritional status in the study children appears to be an important factor in allowing nutritional adaptation to occur. If the data for urinary $\mathrm{Ca}$ excretion in the study children were available, it would help to clarify the argument that nutritional adaptive mechanism exists in growing children to retain an appropriate amount of $\mathrm{Ca}$ for the maintenance of a positive $\mathrm{Ca}$ balance.

The multiple-regression model included three independent variables to predict the intraindividual changes in TFCA over the 6-month period; i.e., treatment effect (either $\mathrm{Ca}$ supplement or placebo), baseline $\mathrm{Ca}$ intake, and the effect of interaction between treatment effect and baseline $\mathrm{Ca}$ intake. The results of the multiple-regression analysis showed that the treatment effect was the only significant independent variable to predict an individual's change in TFCA; baseline $\mathrm{Ca}$ intake had no significant effect on the change in TFCA and there was also no interaction between treatment effects and baseline $\mathrm{Ca}$ intake to predict the individual's change in TFCA. The results imply that the treatment effect (an increased $\mathrm{Ca}$ intake of $300 \mathrm{mg} / \mathrm{d}$ for a period of 6 months) would trigger a downward regulation of the efficiency of $\mathrm{Ca}$ absorption. On the other hand, growing children on self-selected diets not receiving $\mathrm{Ca}$ supplements were still capable of further increasing the rate of absorption to cope with an escalating demand for $\mathrm{Ca}$ for growth. The change in $\mathrm{Ca}$ absorption rate was also found to be independent of the habitual $\mathrm{Ca}$ intake. In other words, the regulation of TFCA may happen in children with either low or high habitual $\mathrm{Ca}$ intake, and the intestinal absorptive mechanism may adapt to different levels of $\mathrm{Ca}$ intake in order to absorb a necessary amount of Ca for growth. Matkovic et al. (1990) and Heaney et al. 
(1975) indicated that $\mathrm{Ca}$ retention in the body is proportional to the total amount of $\mathrm{Ca}$ absorbed. Two early studies on Indian and Sri Lankan children together showed that children with a habitual $\mathrm{Ca}$ intake of about $300 \mathrm{mg} / \mathrm{d}$ could still maintain a positive $\mathrm{Ca}$ balance (Nicholls \& Nimalasuriya, 1939; Begum \& Pereira, 1969). However, contradictory results were found in adolescent Caucasian girls (Matkovic et al. 1990). Although our results show that the children in the placebo group were able to adjust the TFCA upwards, if the diet in childhood is too restricted in Ca content $(<150 \mathrm{mg} / \mathrm{d})$, children may not be able to absorb sufficient $\mathrm{Ca}$ to maintain a positive balance for bone mineralization (Pettifor et al. 1979; Eyberg et al. 1985; Legius et al. 1989).

In conclusion, the present trial evaluated the effects of a 6-month, controlled Casupplementation trial on the TFCA of 7-year-old Chinese children, using the dual stableisotope technique, with ${ }^{44} \mathrm{Ca}$ administered orally in chocolate milk. After the trial the children in the placebo group had a significantly greater mean TFCA than that in the Casupplemented group who ingested an additional $300 \mathrm{mg} \mathrm{Ca} / \mathrm{d}$ throughout the trial. With regard to the individual's adjustment of TFCA in response to the treatment effect (Ca or placebo-treated) after the trial, the control group children showed a significant increase in TFCA, while the Ca-supplemented children had a pronounced but not significant fall in TFCA after the trial. If the mechanism of TFCA from chocolate milk in response to the treatment effects is similar to that from the total diet, then the results of the trial suggest that children with adequate vitamin $\mathbf{D}$ nutritional status were able to adapt in response to a change in dietary $\mathrm{Ca}$ intake by adjusting the efficiency of $\mathrm{Ca}$ absorption. Consequently, children subsisting on a habitually-low-Ca diet would have a higher rate of $\mathrm{Ca}$ absorption than their counterparts with a relatively-higher- $\mathrm{Ca}$ diet.

The study is supported in part by the UPGC Earmarked Research Grant (CUHK 51/91) of the Research Grant Council, Hongkong. The authors are grateful to the study children, parents and teachers who were involved in the study from both Hongkong and Jiangmen. They thank Miss Dora Leung and Miss Heidi Tsang, research nurses, for their assistance in field work; Mr William Tung, Pharmacist, Prince of Wales Hospital, for sterilizing intravenous doses of isotope for injection; Mr C.S. Ho, Department of Chemical Pathology, Prince of Wales Hospital, for assaying the concentrations of the made-up isotopes; Mr Albert Cheung, Centre for Clinical Trials and Epidemiological Research. The Chinese University of Hong Kong, for assistance in statistical analysis; and Mr John Eagles and $\mathrm{Mr}$ Tom Fox, Institute of Food Research, Norwich Laboratory, for their assistance in the stable-isotope analytical work. They also express their gratitude to Professor S. J. Oppenheimer, Department of Paediatrics, and Professor J. R. L. Masarei of the Department of Chemical Pathology of The Chinese University of Hong Kong, and Dr Ann Prentice of MRC Dunn Nutritional Laboratory, Cambridge, for their invaluable advice on the study design. They also thank Smithkline Beecham, Weybridge, Surrey, for supplying $\mathrm{Ca}$ and placebo tablets for the clinical trial. This paper forms part of the thesis of W.T.K.L. for partial requirements for the doctoral degree at the Chinese University of Hong Kong.

\section{REFERENCES}

Begum, A. \& Pereira, S. M. (1969). Calcium balance studies on children accustomed to low calcium intakes. British Journal of Nutrition 23, 905-911.

Bingham, S. A. (1987). The dietary assessment of individuals; methods, accuracy, new techniques and recommendations. Nutrition Abstracts and Reviews 57, 705-742.

Burke, B. S. (1947). The dietary history as a tool in research. Journal of the American Dietetic Association 23, 1041-1046.

Chan, E. P. L., Lau, E., Shek, C. C., MacDonald, D., Woo, J., Leung, P. C. \& Swaminathan, R. (1992). Age- 
related changes in bone density, serum parathyroid hormone, calcium absorption and other indices of bone metabolism in Chinese women. Clinical Endocrinology 36, 375-381.

Chen, C. (1986). The national nutrition survey in China, 1982; summary results (1986). Food and Nutrition 12, 58-60.

Church, C. F. \& Church, H. N. (1975). Food Values of Portions Commonly Used. Philadelphia: J. B. Lippincott Co.

Department of Health, Education and Welfare (1972). Food Composition Table for Use in South East Asia. Washington DC: US Department of Health, Education and Welfare.

Eyberg, C. J., Pettifor, J. M. \& Moodley, G. (1986). Dietary calcium intake in rural black South African children. The relationship between calcium intake and calcium nutritional status. Human Nutrition: Clinical Nutrition 40C, 69-74.

Fairweather-Tait, S. J., Johnson, A., Eagles, J., Ganatra, S., Kennedy, H. \& Gurr, M. I. (1989). Studies on calcium absorption from milk using double-label stable isotope technique. British Journal of Nutrition 62, 379-388.

Food and Agriculture Organization/World Health Organization Expert Group (1962). Calcium requirements. FAO Nutrition Meetings Report Series no. 230. Rome: FAO.

Grindulis, H., Scott, P. H. \& Belton, N. R. (1986). Combined deficiency of iron and vitamin D in Asian toddlers. Archives of Disease in Childhood 61, 843-848.

Heaney, R. P., Saville, P. D. \& Recker, R. R. (1975). Calcium absorption as a function of calcium intake. Journal of Laboratory Clinical Medicine 85, 881-887.

Hegsted, D. M., Moscoso, I., Carlos Collazos, C. H. (1952). A study of the minimum calcium requirements of adult. Journal of Nutrition 48, 181-201.

Heumann, K. G. (1988). Isotope dilution mass spectrometry. In Inorganic Mass Spectrometry, pp. 301-376 [F. Adams, R. Gijbels and R. van Grieken, editors]. New York: J. Wiley \& Sons.

Hillman, L. S., Tack, E., Covell, D. G., Vieira, N. E. \& Yergey, A. L. (1988). Measurement of true calcium absorption in premature infants using intravenous ${ }^{46} \mathrm{Ca}$ and oral ${ }^{44} \mathrm{Ca}$. Pediatric Research $23,589-594$.

Institute of Health (1980). Food Composition Table. Chinese Academy of Medical Sciences. Beijing: Chinese People's Health Publishing Co.

Jain, M. G. (1989). Diet history: questionnaire and interview techniques used in some retrospective studies of cancer. Journal of the American Dietetic Association 89, 1647-1652.

Johnston, C. C., Miller, J. Z., Slemenda, C. W., Reister, T. K., Hui, S., Christian, J. C. \& Peacock, M. (1992). Calcium supplementation and increases in bone mineral density in children. New England Journal of Medicine $327,82-87$.

Lee, W. T. K., Leung, S. S. F., Fairweather-Tait, S., Leung, D. M. Y., Tsang, H. S. Y., Eagles, J., Fox, T., Wang, S. H., Xu, Y. C., Zeng, W. P., Lau, J. \& Masarei, J. R. L. (1994). True fractional calcium absorption in Chinese children measured with stable isotopes $\left({ }^{42} \mathrm{Ca}\right.$ and $\left.{ }^{44} \mathrm{Ca}\right)$. British Journal of Nutrition 72, 883-898.

Lee, W. T. K., Leung, S. S. F., Lui, S. S. H. \& Lau, J. (1993a). Relationship between long-term calcium intake and bone mineral content of children aged from birth to 5 years. British Journal of Nutrition 70, 235-248.

Lee, W. T. K., Leung, S. S. F., Ng, M. Y., Wang, S. H., Xu, Y. C., Zeng, W. P. \& Lau, J. (1993b). Bone mineral content of two populations of Chinese children with different calcium intakes. Bone and Mineral 23, 195-206.

Legius, E., Proesmans, W., Eggermont, E., Vandamme-Lombaerts, R., Bouillon, R. \& Smer, M. (1989). Rickets due to dietary calcium deficiency. European Journal of Pediatrics 148, 784-785.

Leung, S. S. F. \& Lui, S. S. H. (1990). Nutritive value of Hongkong Chinese weaning diet. Nutrition Research 10, 707-715

Malm, O. J. (1958). Calcium requirement and adaptation in adult men. Scandinavian Journal of Clinical Laboratory Investigation 10, Suppl. 36, 108-199.

Matkovic, V., Fontana, D., Tominac, C., Goel, P \& Chesnut, C. H. III (1990). Factors that influence peak bone mass formation: a study of calcium balance and the inheritance of bone mass in adolescent females. American Journal of Clinical Nutrition 52, 878-888.

Miller, J. Z., Smith, D. L., Flora, L., Slemenda, C. \& Jiang, X. (1988). Calcium absorption from calcium carbonate and a new form of calcium (CCM) in healthy male and female adolescents. American Journal of Clinical Nutrition 48, 1291-1294.

Nicholls, L. \& Nimalasuriya, A. (1939). Adaptation to a low calcium intake in reference to the calcium requirements of a tropical population. Journal of Nutrition 18, 563-577.

Nordin, B. E. C. (editor) (1976). Plasma calcium and plasma magnesium homeostasis. In Calcium, Phosphate and Magnesium Metabolism, pp. 186-216. Edinburgh: Churchill Livingstone.

Nordin, B. E. C. \& Marshall, D. H. (1988). Dietary requirements for calcium. In Human Biology, pp. 447-471 [B. E. C. Nordin, editor]. London: Springer-Verlag.

Norman, A. W. (1990). Intestinal calcium absorption: a vitamin D-hormone-mediated adaptive response. American Journal of Clinical Nutrition 51, 290-300.

Norman, D. A., Fordtran, J. S., Brinkley, J., Zerwekh, J. E., Nicar, M. J., Strowig, S. M. \& Pak, C. Y. C. (1981). Jejunal and ileal adaptation to alternations in dietary calcium. Journal of Clinical Investigation 67, 1599-1603.

Paul, A. A. \& Southgate, D. A. T. (1978). McCance and Widdowson's The Composition of Foods, 4th ed. London: H.M. Stationery Office. 
Pettifor, J. M., Ross, P., Moodley, G. \& Shuenyane, E. (1979). Calcium deficiency in rural black children in South Africa - a comparison between rural and urban communities. American Journal of Clinical Nutrition 32, 2477-2483.

Statistical Package for Social Sciences (1990). Base Manual Version 4.0. Chicago, Ill: SPSS Inc.

Tung, T. C., Huang, P. C. \& Li, H. C. (1961). Composition of foods used in Taiwan. Journal of the Formosan Medical Association 60, 973-1005.

Watt, B. K. \& Merrill, H. L. (1983). Composition of Foods. Agriculture Handbook no. 8. Washington DC: US Department of Agriculture.

Woo, J., Swaminathan, R., Pang, C. P., Mak, Y. T. \& MacDonald, D. (1990). A comparison of biochemical indices of bone turnover in elderly institutionalised and free-living subjects. Bone and Mineral 8, 31-38.

Yergey, A. L., Vieira, N. E. \& Covell, D. G. (1987). Direct measurement of dietary functional absorption using calcium isotopic tracers. Biochemical and Environmental Mass Spectrometry 14, 603-607. 